\title{
SESC Pompeia sensorial: experiência na exploração lúdica da arquitetura
}

\author{
MARCELINA GORNI
}

\section{Resumo}

O presente trabalho busca fazer uma leitura do projeto e obra da arquiteta Lina Bo Bardi para o SESC Fábrica da Pompeia (1977-1986), capturado pelo olhar da infância, na relação que tal obra estabelece com os aspectos mais lúdicos e experimentais da existência humana, como invocação da relação dos ambientes com o corpo de seu usuário. Procuramos pontuar e qualificar a importância da experiência sensorial direta com o edifício para alcançar uma compreensão mais plena sobre suas qualidades táteis que lhe conferem um ar de mosaico de cores, texturas, sensações, percursos e movimentos do próprio corpo e tempo no espaço como característica legitimadora dos espaços ali implantados.

Palavras-chave:

Lina Bo Bardi, SESC Pompeia, arquitetura sensorial 


\title{
Sensorial SESC Pompeia: an experience through a ludic journey on architecture
}

\author{
MARCELINA GORNI
}

\begin{abstract}
This present work intents to examine the architectural design and the labor of the architect Lina Bo Bardi for SESC Pompeia Factory (1977-1986) captured by glance of childhood, in relation to establishes with most playful and experimental aspects of human experience, like an invocation of environments relation with one's body. We try to punctuate and qualify the value of straight sensory experience in the building to reach a full understanding on its tactile qualities that give him an assortment facet of colors, textures, feelings, distances and movements of the very body and time in the space as legitimized feature of spaces there introduced.
\end{abstract}

Keywords: Lina Bo Bardi, SESC Pompeia, sensorial architecture 
O

presente trabalho busca fazer uma leitura do projeto e obra da arquiteta Lina Bo Bardi para o SESC Fábrica da Pompeia (1977-1986), capturado pelo olhar da infância, na relação que tal projeto, e mais especificamente, a obra construída, estabelece com os aspectos mais lúdicos e experimentais da existência humana, como invocação/provocação da relação dos ambientes com o corpo de seu usuário. Ao propor o resgate das minhas próprias impressões e experiências infantis, minhas percepções de quando, aos sete anos de idade, frequentava os espaços dos galpões recém-convertidos em espaços de recreação, entretenimento e lazer, buscamos demonstrar como a apreensão do olhar da criança mostra-se elucidativo sobre os aspectos mais fundamentais da obra em si, como os relacionados à sua extrema capacidade de promover experiências lúdicas, sensoriais, e de abrigar as mais diversas possibilidades de exploração das experimentações do corpo no embate com os espaços. Procuramos, dessa maneira, pontuar e qualificar a importância da experiência sensorial direta com o edifício para alcançar uma compreensão mais plena sobre suas qualidades táteis, que lhe conferem um ar de mosaico de cores, texturas e sensações. A relação entre percursos, movimentos do próprio corpo e tempo no espaço são características fundamentais dos espaços ali implantados.

Podemos ainda notar aspectos comuns a outros projetos construídos pela mesma arquiteta, e que são significativos na sua carreira, e que, a nosso ver, estabelecem também essa relação entre corpo, desenvolvimento no espaço, e apelo experimental e flexível de apropriação do espaço pelo seu usuário, além das possibilidades de apropriação espacial com múltiplas funções. O dinamismo das possibilidades de apropriação e percepção do corpo no espaço em projetos como o MASP (1958) e o Teatro Oficina (1983), são características 
determinantes mesmo desses edifícios. Neles notamos aspectos das relações físicas e espaciais fortes, além de um caráter significativo de um aspecto cênico (cenográfico) dos respectivos projetos para com o "espetáculo" que buscam servir de suporte e de elementos de interação. A noção de interação espacial, experimentação com o espaço e com a arquitetura, a participação mais contundente e efetiva do usuário nesses espaços e a incitação a provocar respostas e reações nos usuários são característicos desses projetos, assim como a ação cultural incisiva e veemente da arquiteta, promotora cultural. Tal postura representa um aspecto consonante com as questões elaboradas nos campos das artes cênicas e das artes plásticas do período em que a arquiteta desenvolve tais propostas arquitetônicas: as décadas de 1960, 1970 e 1980.

Para realizar tal análise projetual do SESC Pompeia inicialmente nos propusemos a um olhar inicial sobre o objeto real, no embate corpóreo com a obra construída, através da experimentação pura e genuína, no embate direto com a arquitetura e levantamento fotográfico de seus ângulos inusitados e pouco usuais. Nesse embate, buscou-se (re)estabelecer para mim, enquanto autora da análise, a postura, comportamento e percepção dos espaços, ambientes, materiais e texturas identificados na obra arquitetônica sob um olhar de "primeiridade", um olhar inicial, despido de preconceitos sobre análises arquitetônicas prévias. Tratou-se de intenção deliberada de me (re)encontrar com minhas impressões iniciais sobre a obra, retomando minhas primeiras lembranças e experiências que tive com a mesma, quando, ainda criança, na época da inauguração do SESC e da exposição "Mil brinquedos para a criança brasileira" (1982), tomei contato pela primeira vez com esse complexo de manifestações culturais, lazer e entretenimento localizado no meio do bairro da Pompeia ${ }^{2}$.

Nesse sentido, a visita empreendida ao SESC Fábrica da Pompeia visava à aproximação com essa memória de infância, que me foi marcante na concepção da significação que tais experiências trouxeram para minha própria percepção dos ambientes e das qualidades artísticas neles embutidas. A retomada à postura e ao resgate dessas memórias trouxeram revelações interessantes sobre o caráter da edificação, assim como sobre aspectos do programa de atividades ali desenvolvidos por Lina Bo Bardi. A visita, assim como as posteriores análises textuais e das peças gráficas do complexo (plantas, cortes, croquis, etc.) nos revelou que a problematização central que o edifício aborda trata justamente da convocação de todo o cor- 
po do usuário para a liberdade e a experimentação corporal, a invocação/provocação de sensibilizações e de percepções dos espaços através de suas texturas e materiais trabalhados de maneiras elementares, mas evidenciados e marcados na elaboração da construção.

Na atitude da arquiteta em desenhar imagens, cenas e paisagens cuja clara intenção era que se realizassem na obra concluída, podemos identificar uma relação muito forte da construção histórica (galpões industriais recuperados) com a nova (bloco esportivo), inter-relacionados com elementos naturais, melhor designados pelos seus desenhos de elementos vegetais, arbustos, árvores, e trepadeiras agarrados ao edifício em si. E ainda podemos perceber outros elementos naturais que são levados pela arquiteta para o interior dos ambientes, como o ar, a luz natural, que entram através dos sheds nos telhados dos pavilhões-fábrica preexistentes, assim como pelas aberturas amebóides do bloco esportivo. As presenças da água e do fogo estão garantidas pelas figuras do espelho d'água sinuoso (ou como Bo Bardi o chama, o "Rio São Francisco") e da lareira no pavilhão principal, assim como pela piscina no bloco esportivo. As alegóricas esculturas em vergalhão metálico, chamadas de "flores de mandacarus", assim como o espaço da lanchonete, com seu balcão circular central, marcam fortemente o interior do bloco esportivo, externamente todo construído em concreto aparente.

A experimentação e o embate com aspectos de desenvolvimento corporal dos seus usuários estão implícitos já no relato que a arquiteta faz sobre a sua primeira visita ao espaço em $1976,{ }^{2}$ antes de iniciado o projeto, em que ela toma o primeiro contato com a "festa" da convivência entre as pessoas do bairro e a prática esportiva do futebol realizado por garotos ali naqueles galpões. Assim, percebemos o estabelecimento da proposta projetual de cantos expressivamente tratados em todo o conjunto, texturas que se encontram e se justapõem ao dialogar e animar cada canto (ou junção), em cada detalhe da construção.

A curiosidade e incitação infantis que notamos ao nos sentirmos convidados a explorar cada uma dessas diferenças de texturas, detalhes e planos, materiais, elementos vazados, luzes filtradas e diretas, faz do espaço como um todo um grande caleidoscópio de experimentações, provocações corporais, assim como de elucubrações táteis, traduzidas para o olhar da criança e da infância. Como identificamos em diversos textos da arquiteta e de outros autores, grande parcela do público alvo da proposta são crianças e idosos. O "olhar infantil", puro e 
aberto, está mais predisposto a receber e a se perder no grande mosaico de sensações que a arquitetura ali propõe, de percepções e espacialidades com diferentes ambiências, diferentes qualidades intrínsecas a cada espaço e por isso mesmo, provocador de curiosidade, e similar a um grande brinquedo em escala urbana. Como objeto lúdico, ele convoca a exploração e a novas descobertas da própria relação do usuário-criança com suas possibilidades corporais, sua capacidade de se tornar flexível e olhar, apalpar e perceber as diferentes sutis nuances que os próprios espaços invocam.

O próprio fato da arquiteta ter mudado seu escritório para o canteiro de obras e ter encontrado muitas soluções projetuais e construtivas no mesmo momento e ação da construção, juntamente com os pedreiros e construtores, denota o quanto o caráter de experimentação está presente desde a concepção e desenho dos ambientes. Ao propor testes e embates diretos com os materiais, as tecnologias, os detalhamentos de cada espaço, a arquiteta denota essa preocupação direta com a diversidade no uso desses materiais e texturas desde o processo de projetação e de execução da obra, e não somente para a fruição dos seus usuários após a conclusão da construção. Tratava-se antes de uma realidade e de etapas dos processos de investigação construtiva, projeto arquitetônico, concepção e construção 3 .

Com o presente trabalho pretendemos enfatizar e aprofundar a análise de alguns aspectos sobre o caráter lúdico da proposta, assim como das relações da mesma com as questões do corpo e da percepção sensorial - prioritariamente tátil desse espaço como um todo. O fato de a obra invocar um sentido de experimentação sensorial atrai o interesse de inúmeros usuários do espaço, assim como de arquitetos e estudantes de graduação em arquitetura. Esse é, possivelmente, o aspecto que mais desperta interesse e curiosidade para com a obra em questão. A riqueza, diversidade e profusão de imagens, formas, cores e texturas, faz do espaço do SESC Pompeia um ambiente favorável tanto à infância curiosa, quanto ao idoso. E também se relaciona bem com o adulto que se quer deixar envolver e cujo olhar se permite desenrolar e percorrer todos os detalhes e curiosidades implícitas e explícitas no espaço. $\mathrm{O}$ aspecto lúdico é carregado de significações diversas para cada um de seus usuários.

Sob uma miríade de soluções, encontros e justaposições de materiais e técnicas construtivas tão diversas, a obra pode ser classificada como um verdadeiro bricoleur arquitetônico. Ainda assim, existe de fato uma racionalidade e um 
raciocínio extremamente preciso e rigoroso, que seguem os preceitos mais valorosos da arquitetura modernista e os princípios presentes no Movimento Moderno. Como o próprio arquiteto e parceiro de Lina Bo Bardi nessa empreitada, Marcelo Ferraz reforça em texto comemorativo dos 25 anos de inauguração do SESC Pompeia em 2008, o projeto do complexo do SESC Pompeia é "uma experiência arquitetônica que alia criatividade a um grande rigor, liberdade com responsabilidade, riqueza com concisão e economia de meios, poética com ética" (FERRAZ, 2011, s/p).

Outro aspecto a se destacar é a imagem que se forma na cidade, na paisagem urbana, haja vista sua inserção desde a entrada até os fundos ser predominantemente horizontal e incorporada à malha urbana preexistente, em função da opção de se preservar e se apropriar da própria estrutura e espaços dos galpões da fábrica ali preexistente. Por ouro lado, ao chegar aos fundos da "rua" interna configurada pela seqüência de galpões, temos a grande "surpresa" vertical - a presença dos dois blocos esportivos (um maior contendo as piscinas e quadras poliesportivas, e o outro de serviços, vestiários, salas de ginástica e circulação vertical - escadas e elevador), de 11 andares cada, e que se elevam sobre a paisagem urbana. Tal verticalidade é reforçada em seu conjunto (“cidadela”) pela presença da torre caixa d'água.

A imagem do conjunto de galpões antigos é marcada pela estrutura em concreto Hennebique e vedações em tijolos promovidos pela ação da arquiteta em "descascar" as paredes originais, ao recuperar a estrutura original da fábrica, num claro sentido de tornar clara a "verdade dos materiais" construtivos. A força do coroamento em sheds lhe garante o ritmo, em linhas diagonais repetidas que marcam o telhado e estabelecem a vinculação com o imaginário de fábricas e indústrias antigas da região (do século XIX e primeira metade do século $\mathrm{XX}$ ). Numa extremidade da estrutura predominantemente horizontal, resultante desses ritmos diagonais da cobertura, temos o acesso da rua ao conjunto. Ao passo que na outra, percebemos os blocos maciços e pesadamente implantados ao lado da torre que induz o olhar verticalmente para o alto.

A paisagem é fortemente configurada por essa presença de "bunker" fechado e da caixa d'água vertical, enquanto a estrutura horizontal preexistente se dilui e se confunde com o próprio gabarito do entorno do bairro operário. Pontualmente apenas, reconhecem-se algumas outras estruturas tão delgadas e verticais quanto a da caixa d'água, outras chaminés que 

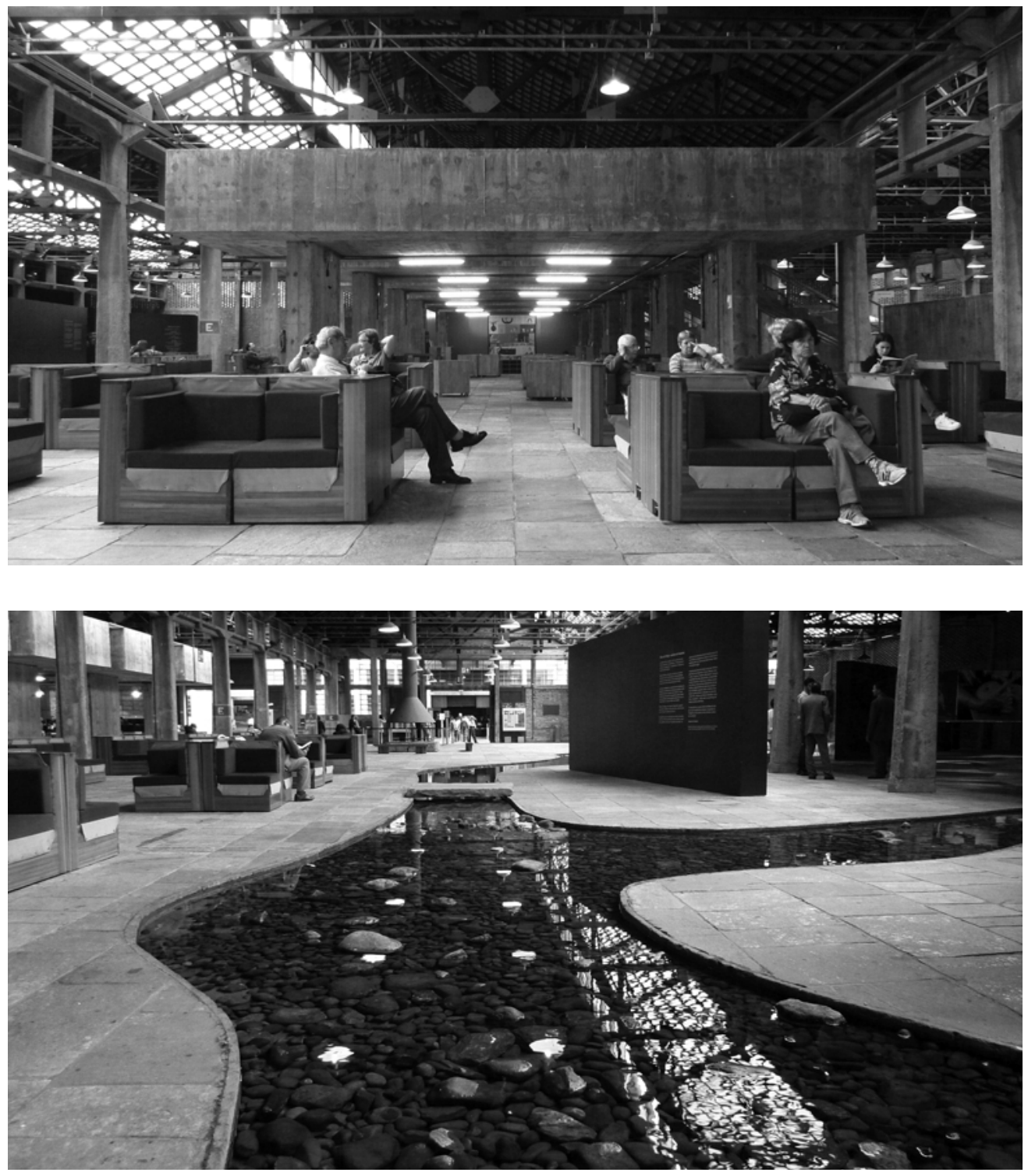

Figuras 1 e 2

Pavilhão multiuso, galpões com amplas áreas de relaxamento, lareira e caixas elevadas da biblioteca. Área de exposições e espelho d'água ("Rio São Francisco"). Fonte: fotos da autora $(03 / 06 / 2011)$ sobreviveram de fábricas antigas e ainda presentes na paisagem, como que insistentes expoentes que reforçam o caráter industrial de um passado recente da região. Toda essa percepção fica evidente ao nos aproximarmos do complexo com o objetivo de localizar e identificar o conjunto do SESC. Em nossa visita, enquanto procurávamos pela localização correta, todas essas imagens apresentavam-se nessa paisagem urbana, reve- 
lando-nos aspectos essenciais de sua inserção urbana e diálogos formais e espaciais com o entorno daquele bairro. Relações de vizinhança comprometida e já acostumada com o edifício da fábrica e que também já não estranha tanto o "monstro-bunker" de concreto com seus olhos vidrados na cidade, meio deformados e distorcidos, em sua expressiva presença.

Provavelmente essa é uma das obras mais poéticas, sugestivas, simbólicas - carregada de inúmeras significações - e enigmáticas que Lina Bo Bardi já produziu e construiu. Sobre as relações que ela busca estabelecer e provocar com o corpo, temos os espaços de descanso e relaxamento no meio do pavilhão multiuso de exposições. Espaços para espreguiçar o corpo, sentar, dormir, relaxar, antes ou depois de um espetáculo ou de praticar um esporte. O corpo distendido e relaxado é o que se invoca.

Espaços para leitura, e a biblioteca estão ali, só que suspensos em caixas de concreto no meio do grande espaço expositivo. Tais caixas suspensas definem espaços inferiores com pés-direitos muito baixos, e que revezam em transmitir uma sensação de aconchego e/ou opressão em função de quem faz a avaliação ou conforme o seu estado de humor (e de espírito) do momento do dia. O interesse nos espaços das tais 'caixas suspensas' está em se enxergar e apreender todo o salão de uma vista "de cima”, através de um ângulo de visão superior privilegiada. Apreensão de 360 graus sobre o espaço amplo (3500m2) do grande salão. Outra relação interessante é a possibilidade de se sentar no chão, sobre tapetinhos ou não, e fazer leituras ali, como se estivéssemos protegidos dentro de uma caverna, dentro de uma grande caixa e assim, ninguém nos vê - brincadeiras de pique-esconde me remetem e me referenciam à sensação de brincadeira que eu tinha ao usar dessa maneira e nessa posição tais ambientes.

A imagem da minha mãe lendo para mim e para meu irmão num canto dessas caixas dava uma sensação de aconchego e proteção. E ao mesmo tempo, invocava a ideia de uma deliciosa traquinagem ao sentir que ali nós três estávamos planejando uma grande estratégia, um plano escondido nas páginas daquele livrinho de histórias infantis, e que ninguém mais poderia estar sabendo, uma vez que conseguimos nos esconder tão bem de todos os olhares curiosos ali no 'canto' de concreto. Sensação de estar brincando de pique-esconde ali, e mesmo estando num espaço aberto, de onde eu podia ouvir tudo o que acontecia ali ao redor, ainda assim, me sentia aconchegada, num espaço protegido. 

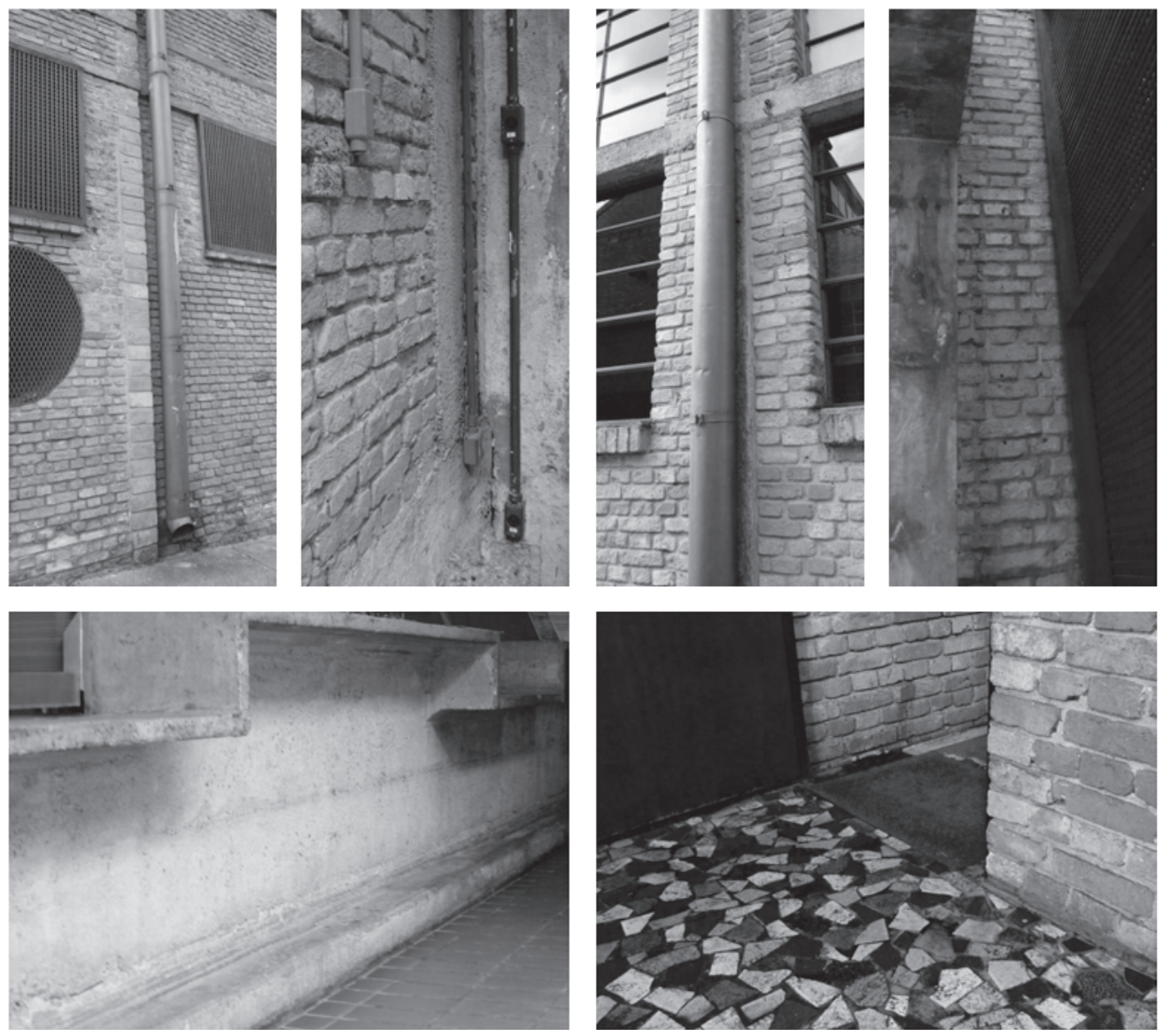

Figura 3

Composição com fotos dos cantos, quinas e junções de elementos arquitetônicos diversos - texturas evidenciadas no encontro entre pisos e paredes. Fonte: fotos da autora
Por outro lado, os mobiliários do restaurante ou as cadeiras de madeira do auditório, nos tiram o sentido de conforto e comodidade de nos "largarmos" comodamente numa macia poltrona. Pelo contrário, o próprio ato de se sentar, torna-se um desafio de atenção e concentração, uma nova relação com o corpo e a postura ao sentar-se, ao embater-se com a maneira de se comportar e de prestar atenção a como o corpo se comporta em determinados ambientes. E por falar no teatro, o auditório de plateia duplicada também remete a outras relações corporais e visuais com o espetáculo. Se nós podemos ver a outra plateia, ela também por sua vez pode nos ver, e isso implica em que nós mesmos, de nosso assento marcado para assistir ao espetáculo, também nos tornamos parte integrante e participante desse mesmo espetáculo - sintonia da arquiteta com os avanços das 

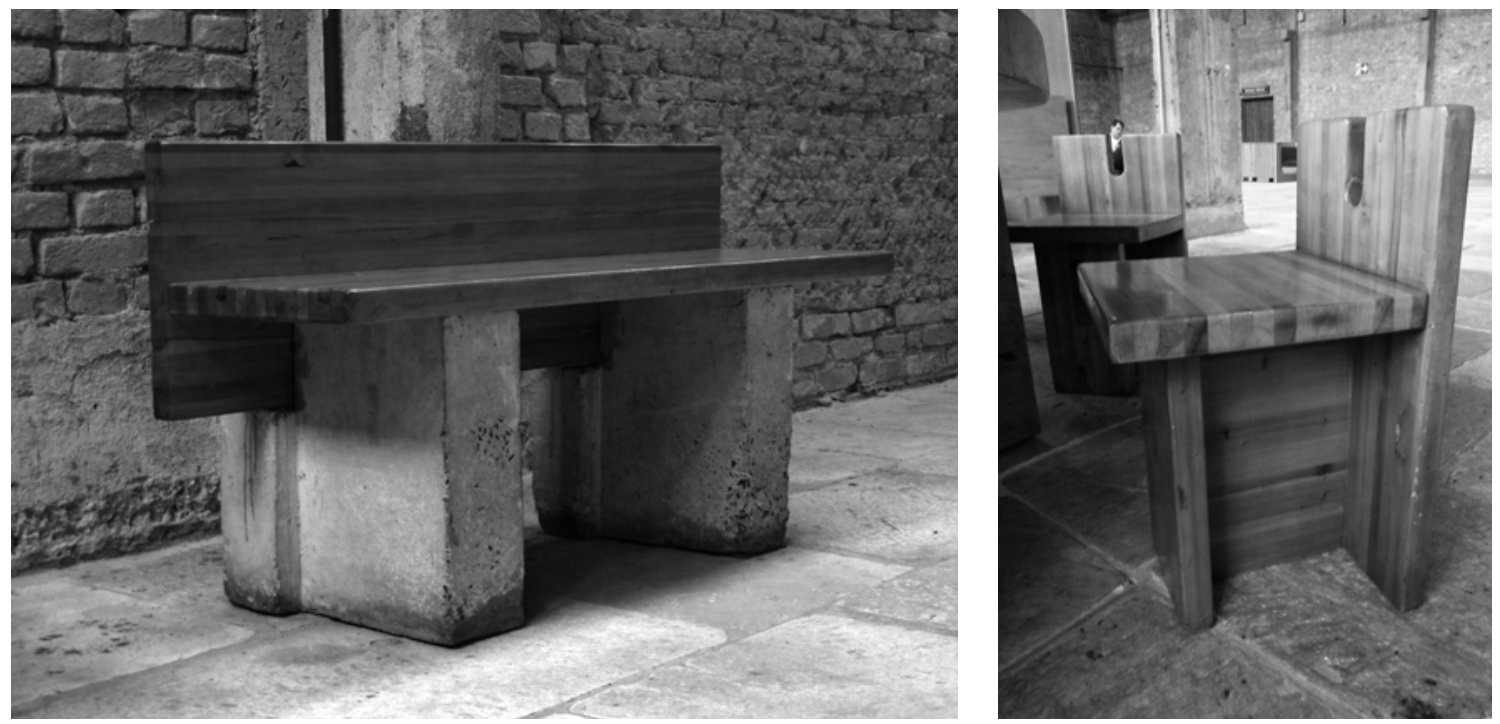

questões e conquistas do espaço cênico rumos a uma utilização integral e plena do edifício como espaço total da caixa arquitetônica, envolvendo todos os espectadores. E a própria rua lateral presente dentro da sala de espetáculos, gera alguns ambientes de camarotes inusitados e que buscam uma ocupação e participação plena dos espectadores na cena que se desenrola no palco.

Ao percorrer a rua interna de paralelepípedos, e magneticamente atraída pelas texturas e encontros de materiais presentes nos diferentes tipos de piso explorados por Bo Bardi, fiquei inevitavelmente atraída e compenetrada nas relações muito peculiares estabelecidas nas duas longínquas e lineares valetas de captação das águas pluviais do conjunto. Valetas essas que me lembraram de outra das minhas preferidas traquinagens de infância: afinal, eram tão amplos e profundos tais espaços, que eu podia perfeitamente me escorar e me esconder dentro deles, assim me arrastando até mergulhar por debaixo das passagens/pontes entre rua e espaço interno dos galpões.

Meu fascínio pelas valetas era tão grande, principalmente em função de sua inusitada materialidade - todas elas eram revestidas de seixos rolados, apresentando uma relação tátil agradável ao corpo, às mãos, aos joelhos e aos pés. Tão agradável que me arrastar por elas agachada engatinhando, era uma das minhas atividades favoritas durante as visitas ao SESC naqueles anos de minha infância. Achava ainda mais interessante passar por debaixo das "passarelas-pontes" de concreto
Figuras 4 e 5

Banco e cadeira em madeira, desenhados por Lina Bo Bardi - assim como as poltronas do teatro. Mobiliário que requer uma determinada postura corporal de seu usuário. Fonte: fotos da autora (03/06/2011) 
brincadeira de interagir com os ambientes, ao explorar sensorialmente aqueles espaços. São Paulo é uma cidade dura, fechada, sem espaço de exploração para a maioria das crianças, não se tem liberdade de experimentação do corpo no espaço em qualquer lugar, pois a maioria dos lugares públicos pressupõem um comportamento e postura precisos e rígidos, não livres e soltos. O SESC Pompeia, ao contrário inclusive das ruas paulistanas, era o lugar onde a minha infância procurava estimular a exploração e a descoberta das possibilidades de escala e de relações do corpo solto e livre no espaço. Liberdade e exploração corporal é o que eu sentia quando criança ia passear pelos espaços. O espaço "conversava" comigo criança, tinha a minha escala, na qual eu me aconchegava. E também vivenciava outras situações, como a do bloco esportivo, de uma escala monumental, impositiva e assustadoramente enorme.

O SESC dialoga com aspectos da obra de Aldo Van Eyck, importante arquiteto holandês, integrante do Team $\mathrm{X}$ e que busca, através de uma pesquisa antropológica, estabelecer uma crítica em relação à depuração exagerada de alguns exemplares modernistas. O seu Orfanato em Amsterdã (196061), que entre outras características, adota uma 'forma aberta', onde a malha geométrica define espaços neutros, que possam ser apropriados e usados por seus usuários, assim como formas arquetípicas. Trata-se de um projeto que busca estabelecer elementos que sejam pensados adequados à escala ideal da criança. De modo similar, o SESC dialoga bem com essa escala da infância, através de sua enfatizada horizontalidade, dos detalhes e rebuscamentos das texturas e dos materiais sabiamente explorados e combinados entre si, criando encontros e acasos interessantes, 'conversas' alegres e coloridas.

Assim como o Centro Georges Pompidou na França, ele demonstra o funcionamento da edificação pela exposição das suas tubulações, circulações, instalações elétricas, hidráulicas, etc.

No restaurante e choperia do SESC Pompeia, a profusão de tubulações, estruturas em madeira dos telhados, coifas de fogões, instalações elétricas, etc., é de uma expressão muito forte dessas múltiplas confluências de sistemas coloridos. Ao explicitar como o edifício funciona, este estabelece um alto grau de comunicabilidade com seu usuário - o edifício é vivo e as pessoas podem vê-lo, tocá-lo, senti-lo e tateá-lo, percebendo assim como ele se estrutura, como se organiza e realiza o seu programa de funções. De dentro para fora, as 'vísceras' do edifício são expostas, da mesma maneira como o fazia o casal inglês Peter e Alison Smithson, importantes integrantes do Team X, em seus 

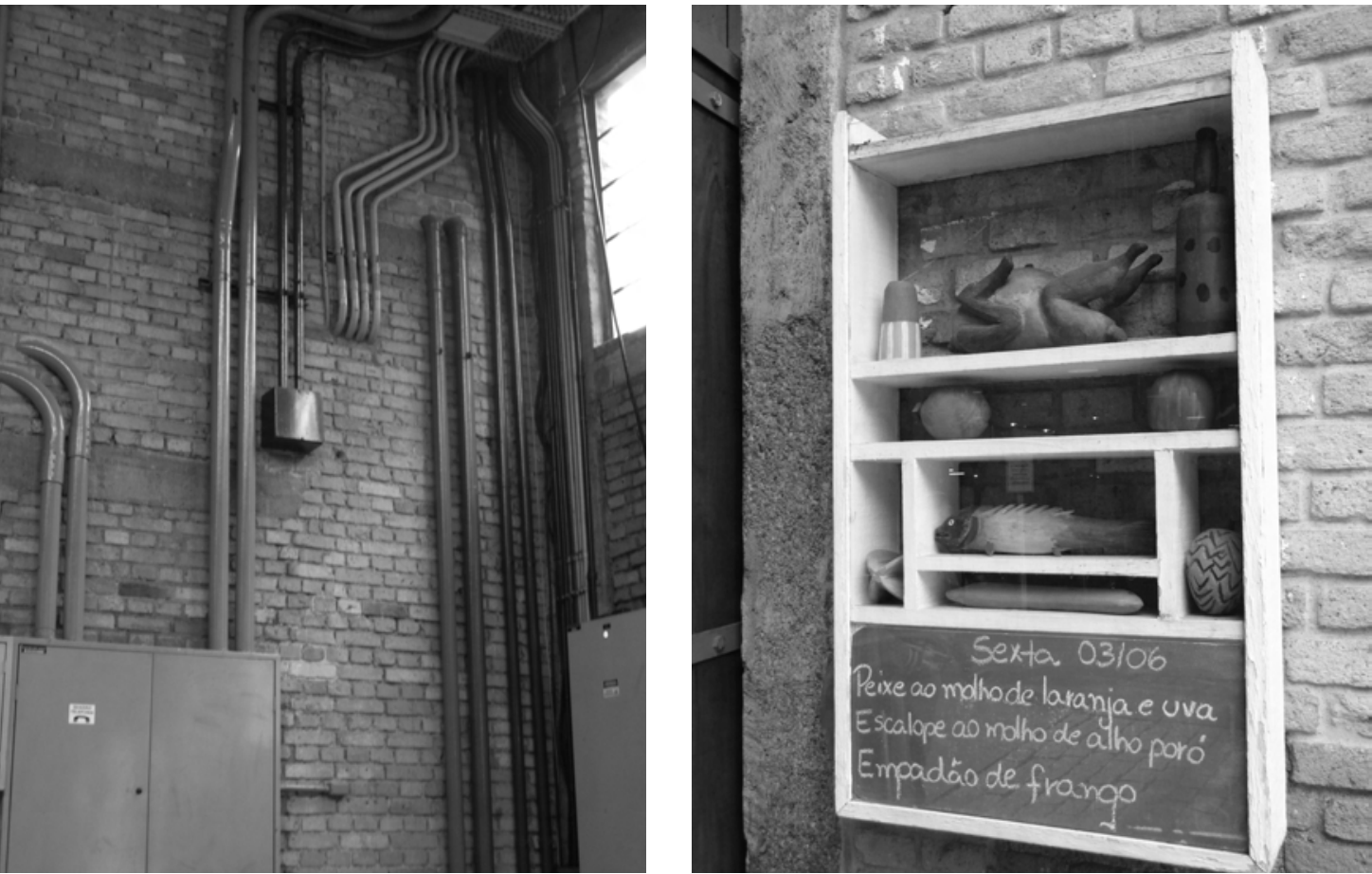

Figuras 7 e 8

Instalações aparentes presentes em todo o conjunto;

e comunicação visual na frente do restaurante. Fonte: fotos da autora (03/06/2011) projetos chamados de 'neobrutalistas' por Reyner Banham, em particular num de seus primeiros projetos, a Escola Secundária de Hunstanton (1949-54) ${ }^{4}$ - não por acaso, também um projeto pensado para uso prioritariamente de crianças.

Para a criança, isso dá um ar de magia e encantamento à estrutura do lugar em que se está, e o próprio edifício tornase o ato da brincadeira, torna-se a própria dica das metáforas brincantes que ele mesmo evoca. Um exemplo de um anúncio lúdico presente no restaurante é o quadro de "peças comestíveis" feitas artesanalmente em madeira e colocado na porta do restaurante a anunciar os pratos do dia na lousa afixada.

Ao lado do teatro, está o galpão preparado a meias paredes para receber aquelas pessoas que querem se aventurar com as mãos, com os pés, com todo o corpo em atividades frequentemente quase terapêuticas de aprender uma nova técnica, uma nova atividade manual. As oficinas de artesanato têm esse caráter de dar às pessoas a possibilidade de se "pensar com as mãos”, de desenvolver uma atividade eminentemente manual e tátil, de se embater com os materiais e aprender a dominá-los na confecção de objetos, imagens, texturas, e novas relações perceptivas, sensoriais e espaciais. 


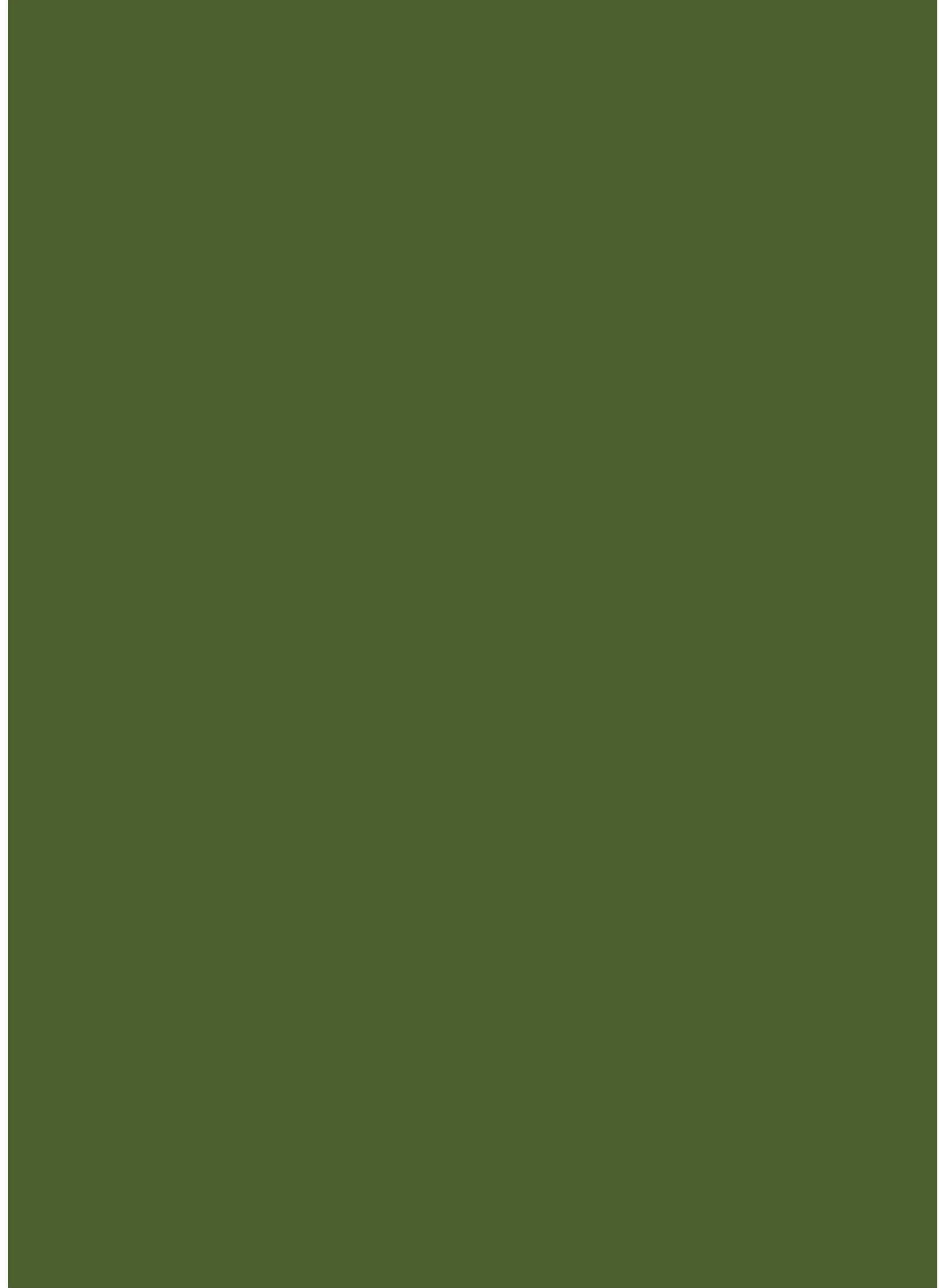




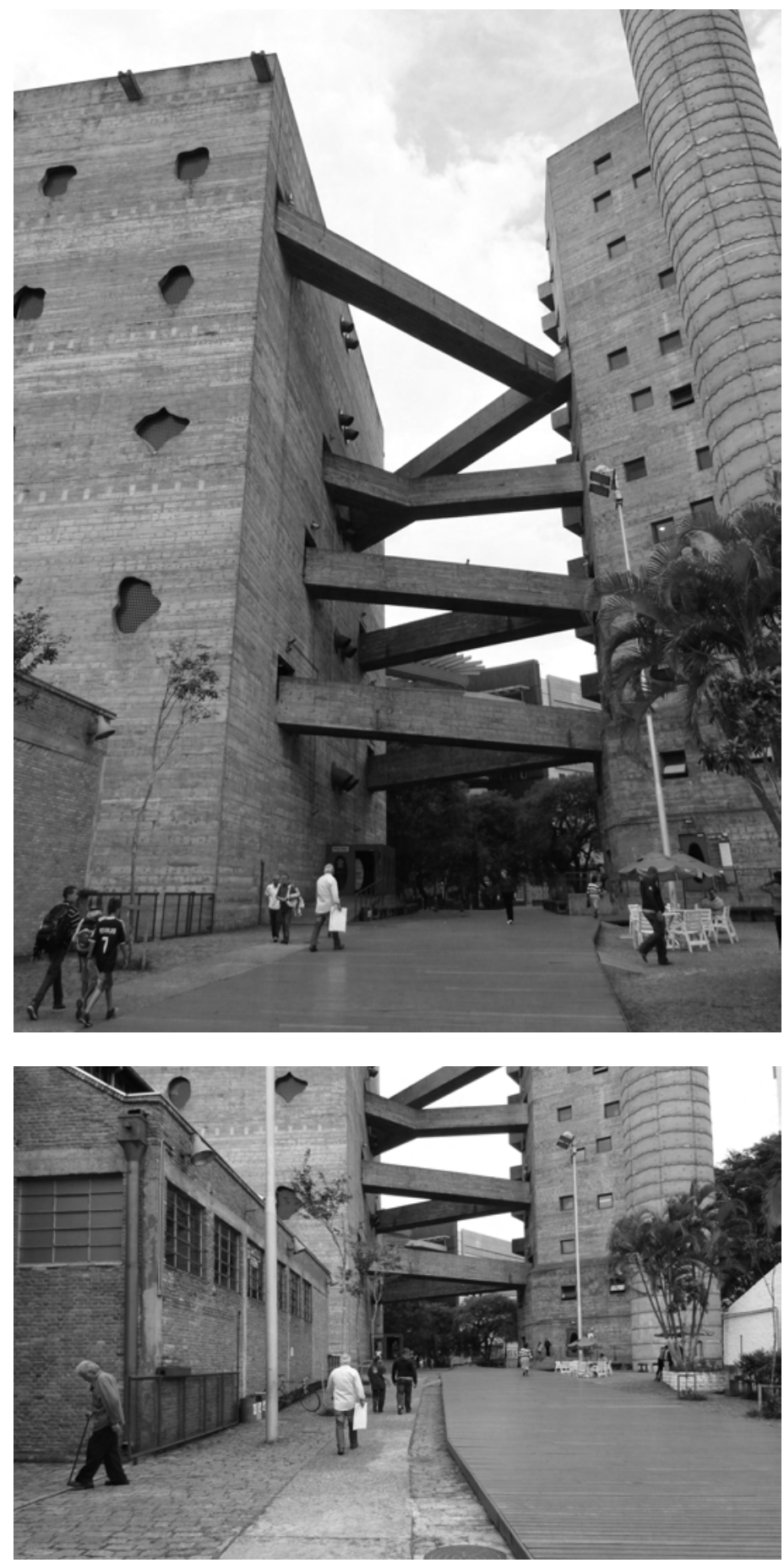

Figuras g e 10

Vistas do conjunto esportivo com as passarelas que amarram os dois blocos entre si, a partir do deque de madeira. Fonte: fotos da autora (03/06/2011) 
A relação com o corpo que se joga no espaço também se apresenta nos corpos seminus largados ao deque em busca de um pouco de sol, na "praia" popular - o naco de sol que os paulistanos podem encontrar no meio da selva de pedra. Dali para as ações corporais fortes e de embates prementes que acontecem nas quadras, ginásios, piscinas, salas de ginástica, etc., estamos a apenas um pulo, ou um elevador, ou uma escada helicoidal - já estamos ali no deck, ao lado da torre esportiva.

A impressão que se tem do projeto proposto por Bo Bardi para o SESC é que seu grande sucesso deve-se também, em grande parte, a imensa sincronicidade entre programas de atividades, formas arquitetônicas, distribuições espaciais e a capacidade de gerar participação, interação e envolvimento dos usuários com a própria arquitetura ali proposta. "Percurso", um grande percurso lúdico, interativo é o que melhor qualifica o conjunto como um todo. Se fizermos um percurso, um trajeto, passando por todos e por cada um dos espaços - como de fato eu o fiz, percorrendo e buscando recuperar as imagens e experiências que tive na minha infância dentro daqueles espaços - começando pela entrada e entrando em cada um dos ambientes, no grande pavilhão, nos sanitários, no bar e restaurante, no foyer e no teatro, nas áreas de oficinas artesanais, até chegarmos aos fundos, com seu grande deque de madeira e as torres de esportes com sua escada externa de concreto para emergência, veremos que a maioria massacrante dos ambientes explora alguma relação do usuário com seu próprio corpo ou a relação entre corpos diferentes a embaterem-se numa atividade eminentemente física e tátil.

A prática do lazer ali desenvolvido está intimamente associada às práticas corporais que evocam alguma relação de prazer, experimentação, satisfação corporal e/ou relaxamento e divertimento. Induzir a certas posturas físicas e corpóreas, a determinados comportamentos e trajetos, maneiras específicas do corpo humano se portar, sempre foi uma característica e uma das mais típicas consequências de qualquer edificação ou conformação urbanístico/arquitetônica. Mas ao eleger como um ponto de partida do processo de projetação arquitetônica tais relações com o corpo e com os diversos níveis de percepção, Bo Bardi radicaliza e leva ao limite a exploração desse tipo possibilidade de experimentações sensoriais.

Além dessa relação sensorial, ao projetar o SESC em seus desenhos iniciais, Bo Bardi faz a indicação de muitas rampas e passarelas interconectadas sinuosamente nos interiores dos 
galpões. Foram desenhados por ela sequências de espaços labirínticos para os ateliês de artesanato em croquis datados ainda de 1977. Tais desenhos indicam a vontade de que o movimento, os trajetos e os percursos já fossem um significativo dado do projeto, uma qualidade intrínseca do espaço ali materializado. Os trajetos múltiplos, passarelas aéreas, demonstram como esses elementos lançados pela arquiteta definem uma riqueza e diversidade de qualidade dos ambientes.

A diversidade de trajetos e escalas no projeto leva-nos a percepções variadas. Tais opções projetuais reforçam também o convite constante à descoberta e à renovada exploração dos espaços. Cada ambiente permeado de labirintos, passarelas, passagens, rios, caixas de leitura, etc., dão a sensação de um constante "mistério" espacial sendo paulatinamente revelado. Cada um dos ambientes dentro de galpões e torres nos convida a ser desvendado, o que é particularmente instigante para a já inerente curiosidade infantil.

Ao analisar a concepção do projeto de Bo Bardi para o SESC, Olívia de Oliveira, pesquisadora da obra da arquiteta, comenta que "o movimento e a circulação das pessoas é o tema primordial do conjunto. (...) A 'cidadela' nasce daqueles movimentos de deriva entre os pavilhões da antiga fábrica, que Lina observou nos fins de semana em que ali esteve, sobretudo no que diz respeito às crianças" (OLIVEIRA, 2006, p. 221). Para a autora, a ideia dos "percursos" é fundamental para a obra de Bo Bardi e estes constituem-se enquanto "lugares" verdadeiramente qualificados utilizados para espaçar a noção temporal. E ela complementa a ideia dos percursos associada à noção de tempo estendido na obra de Bo Bardi, dizendo: "E ao dilatar o tempo, dilatam-se também as sensações e percepções do lugar. O SESC é o melhor exemplo para compreender essa noção de tempo diretamente associada ao movimento do corpo no espaço, não aquele de um caminhar distraído e rotineiro, mas de uma dança livre feita com todo o corpo desperto" (OLIVEIRA, 2006, p. 221). Esse livre desenvolver-se no espaço, passear pelos trajetos que a arquiteta indica, dilatando-se a noção de tempo/espaço, transforma-se em livre entretenimento e envolvimento com cada um dos detalhes e curiosidades que os edifícios apresentam.

A observação e envolvimento com a 'sensorialização' da própria arquitetura do SESC, torna-se entretenimento. Ao buscar a recuperação das minhas memórias de infância, mais uma vez, senti o tempo dilatar-se e, distraidamente, me envolvi com os ambientes, de modo a perder a noção o tempo real. Entre 


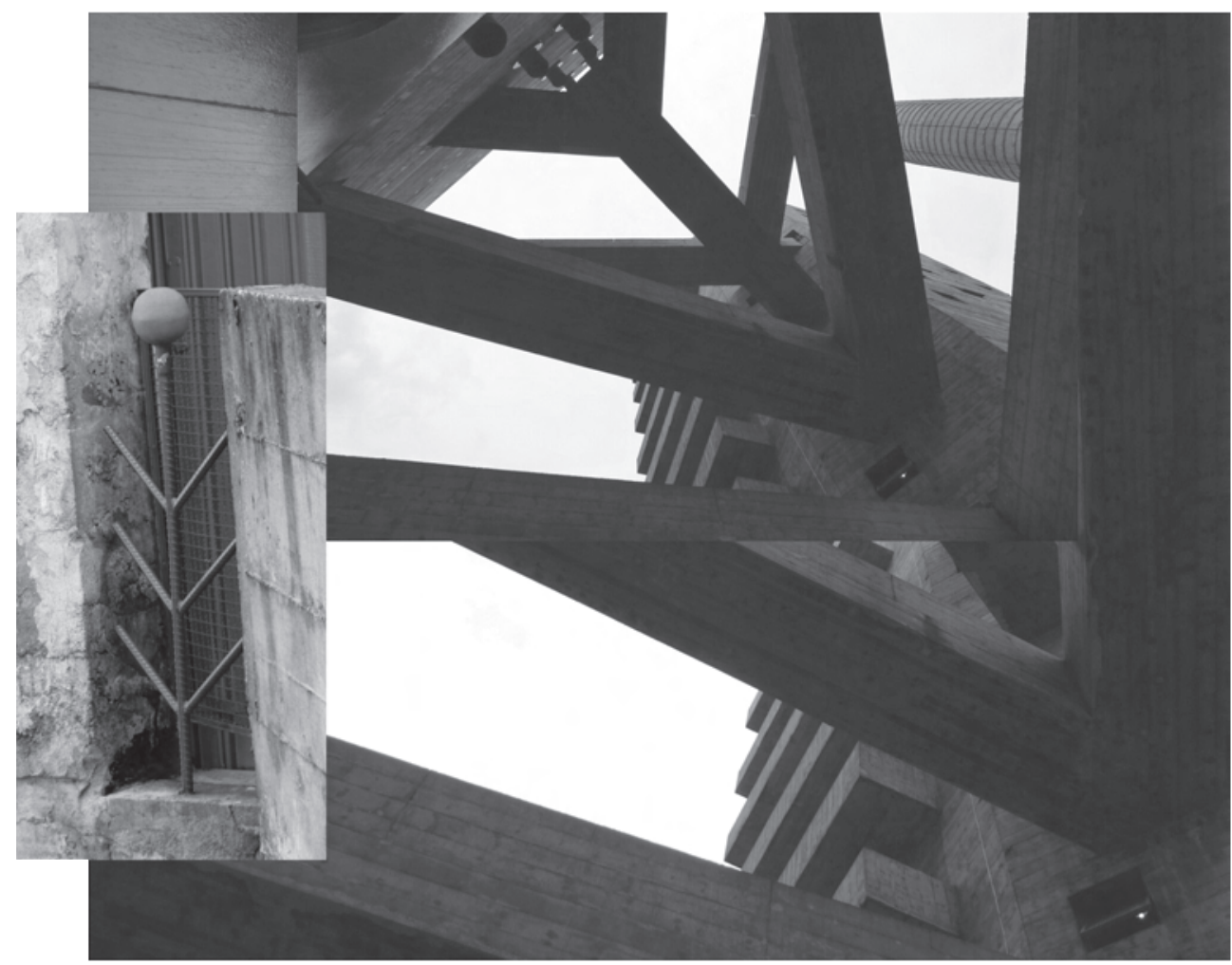

rias do foyer do teatro. Cada detalhe e cada canto é recheado pequenas surpresas espaciais e têxteis.

Por outro lado, podemos notar um movimento que reforça o sentido amplo, vertical e imponente nos blocos esportivos, amarrados entre si por passarelas que simulam, se vistas em projeção, o desenho das "flores de mandacarus". Em uma escala grandiosa e preponderante, observamos o movimento ascensional, proeminente e altivo - uma presença marcante e fortificada.

Se a horizontalidade predominante nos galpões antigos levam nossos olhos ao chão, aos cantos, aos detalhes, às tubulações e calhas aparentes, além do contato direto com a "tatibilidade" de cada componente e de cada material específico, a forte presença vertical dos blocos esportivos apelam para a elevação do olhar para o alto, e o movimento é de subida. $\mathrm{O}$ tempo de percurso nas torres é guiado pelos trajetos verticais (escada helicoidal e elevadores), assim como pelas passarelas que interligam os blocos. É possível, dessa maneira, associar-
Figura 13

Composição mostrando similaridade entre a estrutura formal das passarelas aéreas vistas em projeção, a partir do térreo e elemento em vergalhão de ferro que remete à imagem da "flor de mandacaru".

Fonte: fotos e montagem da autora (junho/2011) 
mos os galpões antigos restaurados como sendo mais voltados e adequados ao tempo de desenvolvimento de crianças e idosos no espaço - mais lento e vagaroso - ao passo que as torres esportivas dedicam-se a materializar o tempo e o movimento dos jovens e adultos - mais rápido e ágil.

Ao comentar sobre a relevância das questões ligadas ao tratamento do corpo no espaço para a proposta do SESC, Lina Bo Bardi escreve no texto de apresentação do seu projeto, em 1986:

Nas grandes civilizações do Extremo Oriente como o Japão e a China, a postura cultural do corpo (corpo como "mente") e o exercício físico coexistem. No Brasil coexistem também, só não existem na classe média, e o verdadeiro problema é uma ação para o autoconhecimento de baixo para cima e não de cima para baixo. A respeito do Centro da Pompéia, o Centro Esportivo é Centro Esportivo, Físico, dedicado especialmente aos jovens das padarias, açougues, quitandas, supermercados, lojas e lojinhas, que os freqüentavam antigamente como eu os vi em ' 76 e ' 77 , e que hoje sentem-se defraudados. Para Homens e Mulheres, o domínio físico tem limite de idade. Para as crianças também, que poderão ocupar os espaços desde o começo definido como 'Palestra', no Estudo 'Espaço' NOBRE, no sentido latim da palavra, espaço também dedicado a festas, reuniões e dança. (BO BARDI, 1986, in INSTITUTO LINA BO e P. M. BARDI, 1999, p. 40)

Como a própria arquiteta indica em um de seus croquis de 1977, os primeiros pavilhões, mais amplos, dedicados a múltiplos usos e exposições, também abrigaria espaços interligados por passarelas e dedicados às crianças. $\mathrm{O}$ texto e os desenhos da arquiteta já indicam a presença predominante de adolescentes, jovens e adultos nas torres esportivas verticais. Todos os seus desenhos também mostram os usuários percorrendo e apropriando-se dos espaços em movimentos de dança.

O próprio conjunto arquitetônico, lido e encarado pelo usuário como um imenso e misterioso brinquedo urbano (ou parque de diversões) a ser desvendado, promove interação dos mesmos com os seus espaços, despertando a sensação de se estar participando de um grande jogo lúdico, onde compactuamos com a arquiteta em brincar com seu brinquedo, em jogar com as suas regras. Percorrer esses espaços é desvendar seus segredos e mistérios em um jogo sempre aberto a novidades. A curiosidade infantil é altamente instigada por essa proposta, uma vez que está aberta a se aventurar no inusitado. A imagé- 
tica vinculada às fantasias infantis sempre estive presente e associada à própria concepção arquitetônica e artística do SESC. A própria arquiteta chamou de 'cidadela' a todo o conjunto de torres verticais, atribuindo valor e significado de verdadeiras fortificações medievais às estruturas fechadas e herméticas das torres esportivas, como os "fortes" militares brasileiros.

Os aspectos lúdicos e cênicos da obra estão denotados nos apelidos que Bo Bardi dava a cada um dos elementos arquitetônicos que iam compondo os espaços: o espelho d'água com seixos rolados como "Rio São Francisco", a ducha de água, como "cachoeira”, as estruturinhas de vergalhão metálico de fechamento dos pavimentos do bloco de circulações verticais apelidadas de "flor de mandacaru", a escada helicoidal vermelha apelidada de "escada gaiola”, e a própria estrutura da caixa d'água chamada por ela de "torre chaminé da caixa d'água”. Metáforas que enriquecem de significações cada um dos ambientes.

Na transposição do escritório arquitetônico para o local da obra, a arquiteta passa a tomar as decisões projetuais no próprio canteiro de obras e, muitas vezes, com a colaboração ativa dos operários. Essa postura com alta carga política tem fortes vínculos com a arquitetura de Sérgio Ferro, Rodrigo Lefèvre e Flávio Império, em sua crítica à alienação desses operários da construção civil em relação aos processos de construção dentro dos canteiros de obra brasileiros. Bo Bardi, dessa maneira, compartilha com esses arquitetos uma postura alinhada à "poética da economia" defendida por eles ainda durante a década de 1960. Assim, os momentos de concepção e execução da obra arquitetônica passam a mesclar-se, e a participação do operário na concepção/construção passa a ser bem mais efetiva e definidora da proposta final edificada. Tais soluções são adotadas a partir da exploração criativa de materiais e técnicas convencionais que passavam pela aprovação final da arquiteta. ${ }^{5}$

Essa proposta de concepção também lança a própria arquiteta no direto embate com o seu próprio "jogo" ou "parque de diversões". Essa postura implica em definições no próprio canteiro de todos os detalhes do projeto, desde a comunicação visual do conjunto até todo o seu mobiliário passa a ser definido e detalhado pela arquiteta em conjunto com os operários. Usando materiais e técnicas construtivas elementares, de um modo bastante livre, inusitado e criativo, a arquiteta coloca-se ali também em uma postura de "criança", com olhar de "primeiridade", que parte de princípios imagéticos criativos os mais diversos.

Segundo Walter Benjamin, todo o planeta está repleto de 
objetos que são fontes de atenção e da ação das crianças. Num texto intitulado "Canteiro de Obras", o autor evidencia como as crianças tem a forte capacidade criativa desenvolvida, de modo que são capazes de tornar todo e qualquer objeto a sua volta, uma possibilidade de frutíferas relações imagéticas, capazes de lhes imprimir novos e inusitados significados com qualidades metafóricas específicas. Também dessa maneira trabalha Bo Bardi com os materiais, técnicas e elementos construtivos. O autor comenta sobre a ação das crianças em qualquer campo que se encontrem:

Sentem-se irresistivelmente atraídas pelos detritos que se originam da construção, do trabalho no jardim ou em casa, da atividade do alfaiate ou do marceneiro. Nesses produtos residuais elas reconhecem o rosto que o mundo das coisas volta exatamente para elas, e somente para elas. Neles, estão menos empenhadas em reproduzir as obras dos adultos do que em estabelecer entre os mais diferentes materiais, através daquilo que criam em suas brincadeiras, uma relação única e incoerente. Com isso as crianças formam o seu próprio mundo de coisas, um pequeno mundo inserido no grande (BENJAMIN, 2002, p. 104).

Ao estabelecer novas relações entre os materiais inusitados justapostos, a fazer dialogar os elementos, os sistemas de captação e condução de águas pluviais, os condutores elétricos, a conjugação entre o concreto e os tijolos aparentes, as pedras, acabamentos, estruturas que se colocam no meio dos edifícios, etc., a arquiteta condiciona uma série de elementos que, agindo em conjunto, remetem-nos a esse novo universo do jogo, do grande brinquedo urbano que ali se configura. Um universo muito próprio de coisas, uma independente "cidadela" muito específica inserida na grande cidade de São Paulo.

O corpo solto e liberto em seus movimentos é sugerido o tempo todo pelos próprios espaços que Bo Bardi constrói. A participação e solicitação do usuário nos espaços do SESC Pompeia é identificável ao tipo de participação sugerida aos visitantes de museus por artistas como Hélio Oiticica, Lygia Clarck e pelo próprio Teatro Oficina nos anos 1960 e 1970. A arquitetura de Bo Bardi aqui, como uma arquitetura falante, que se comunica e instiga a interação, uma participação do usuário, convidando-os a tomarem atitudes e posturas ativas. Tira-se assim o usuário de certa "passividade" corporal, de uma postura de priorização do "visual" sobre o "sensorial" 


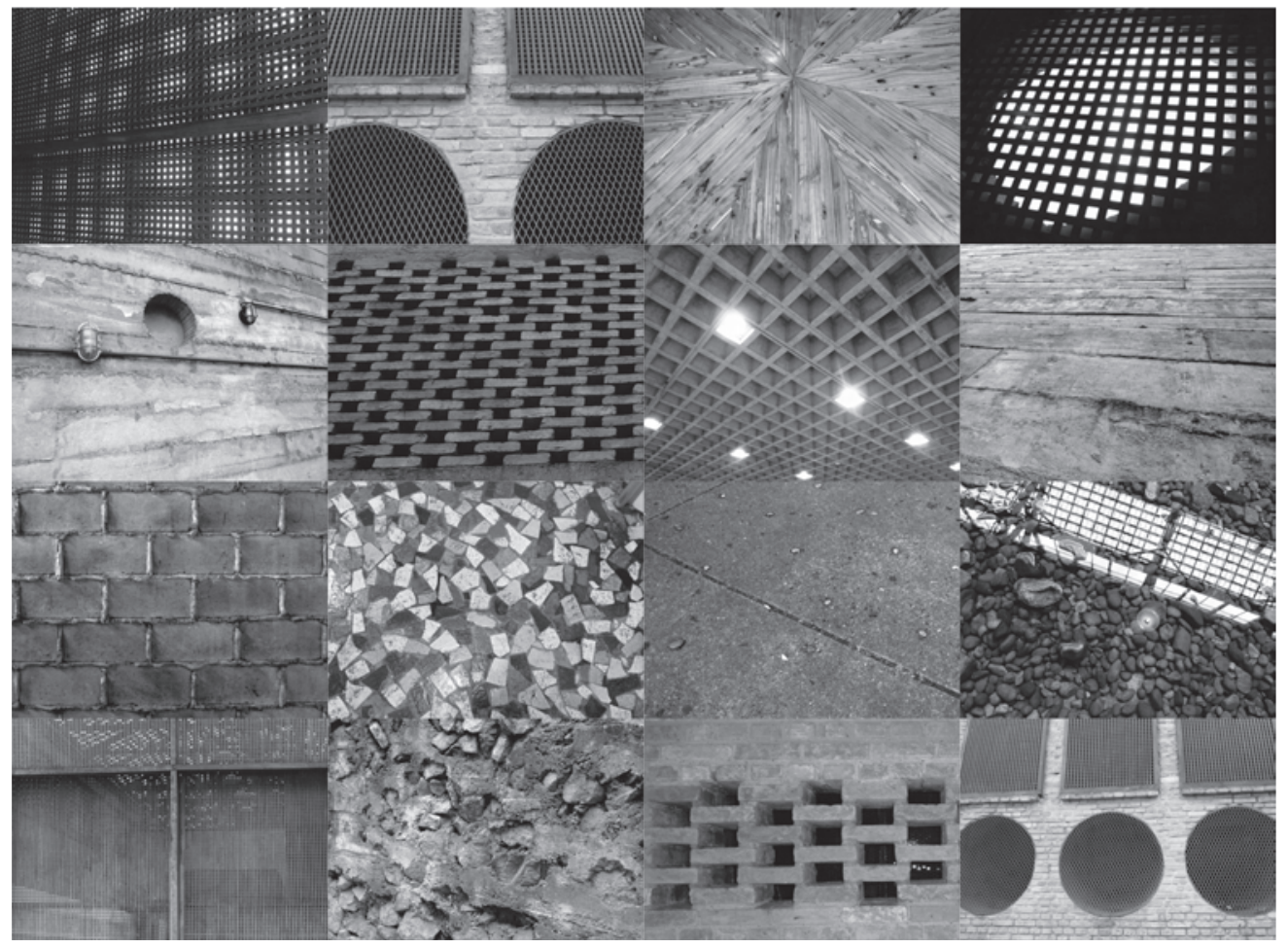

característica de outras edificações arquitetônicas. Toda obra de arquitetura, em maior ou menor grau, já é imbuída de certo apelo interativo, pressupondo a interação do usuário com o ambiente no qual ele está inserido ${ }^{6}$. A respeito disso, a própria arquiteta comenta no mesmo texto para a inauguração do bloco esportivo do SESC de 1986: "Os espaços de um projeto de arquitetura condicionam o homem, não sendo verdadeiro o contrário. E um grave erro nas determinações e uso desses espaços pode levar à falência toda uma estrutura" (BO BARDI, 1986, in INSTITUTO LINA BO e P. M. BARDI, 1999, p. 40).

A arquitetura do SESC incita e convoca ainda mais enfaticamente à efetiva interação dos seus usuários, exercitando os seus sentidos. A participação é reforçada nas imagens, texturas, formas, direcionamentos e relações entre essas diferentes escalas do corpo e dos movimentos suscitados aos usuários da micro à macro escala.

$\mathrm{O}$ que transparece e marca a nossa a(com)preensão do SESC Pompeia nesse contexto de análise, ao final desse percurso e de um debruçar-se sobre o objeto, com esse "olhar de primeiridade”, é o imenso mosaico de texturas, materiais,
Figura 14

Síntese formal/conceitual do SESC Fábrica da Pompeia mosaico de texturas e materiais diversos justapostos, ordenados sob uma racionalidade intrínseca. Fonte: fotos e montagem da autora (junho/2011) 
estruturas, técnicas, ambiências, relações espaciais, de usos múltiplos a serem desenvolvidos em conjunto no complexo. $\mathrm{O}$ SESC Pompeia, enquanto mosaico, ainda é caracterizado por uma racionalização arquitetônica muito rigorosa, que organiza e sistematiza tudo, a partir de uma conepção profundamente modernizante. De modo que é possível ordenar o profuso, sensual, confuso e multicolorido complexo do SESC Pompeia como uma grande colcha de retalhos, como um patchwork específico. A racionalidade implícita que deixa explícito o exercício das múltiplas possibilidades de percursos, movimentos e passagens, permite uma exploração maior das suas ricas qualidades táteis e ambientais. Em função de seu próprio sentido predominantemente tátil, os múltiplos significados que tal obra arquitetônica pode assumir é de mais evidente percepção quando vivenciados in loco. Uma obra que só pode ser plenamente compreendida, tanto em sua total e diversificada abrangência quanto em seus mínimos detalhes, ao realizarmos o embate direto e corpóreo com a mesma.

\section{Referências}

ARGAN, G. C. Arte Moderna: do Iluminismo aos movimentos contemporâneos. São Paulo, Cia. das Letras, Ed. Shwarcz, 1993.

BENJAMIN, W. Reflexões sobre a criança, o brinquedo e a educação, São Paulo, Duas Cidades; Ed. 34, 2002.

BO BARDI, Lina. Tempos de Grossura: o design no impasse, $1^{\underline{a}}$ ed, São Paulo, Instituto Lina Bo e P. Maria Bardi, 1994.

CORREA, José Celso Martinez. Teatro Oficina: osso duro de roer, in: "Lina Bo Bardi - Teatro Oficina (1980-84)", Lisboa, Instituto Lina Bo e P. M. Bardi, Editora Blau, 1999.

FERRAZ, Marcelo (org.). Lina Bo Bardi, São Paulo, Instituto Lina Bo e P. M. Bardi, 1993.

. Numa velha fábrica de tambores. SESC-Pompéia comemora 25 anos. Minha Cidade, São Paulo, 08.093, Vitruvius, abr. 2008, disponível no site: <http://www.vitruvius. com.br/revistas/read/minhacidade/o8.093/1897>. Acessado em 02 de julho de 2011.

FRAMPTON, Kenneth. História Crítica da Arquitetura Moderna. São Paulo, Ed. Martins Fontes, 1997.

FURQUIM WERNECK LIMA, Evelyn. Por uma revolução da arquitetura teatral. O Oficina e o SESC da Pompéia. Arquitextos, São Paulo, 09.101, Vitruvius, out 2008, disponível 
em: <http://www.vitruvius.com.br/revistas/read/arquitextos/o9.101/100>, acessado em 27 de agosto de 2010.

INSTITUTO LINA BO E P. M. BARDI, Cidadela da Liberdade, catálogo da exposição, SESC São Paulo, 1999.

OLIVEIRA, O. Lina Bo Bardi: obra construída. Barcelona, Gustavo Gili, 2002. . Sutis substâncias da arquitetura. São Paulo, Romano

Guerra; Barcelona, Gustavo Gili, 2006.

PEREIRA, Juliano Aparecido. Lina Bo Bardi: Bahia 1958-1964. Uberlândia, EDUFU, 2007.

SILVA, M. B. Lina Bo Bardi: arquitetura cênica, dissertação de mestrado, EESC-USP, São Carlos, 2004.

NOTAS

1. Tal exposição, que aconteceu entre dezembro de 1982 e julho de 1983, está amplamente documentada com fotos e imagens dos cartazes que Lina Bo Bardi executou para a sua divulgação em dois livros publicados sobre a obra da arquiteta, juntamente com outras exposições que a arquiteta organizou junto ao SESC Pompeia na década de 1980. Şobre tais exposições, consultar: Instituto Lina Bo e P. M. Bardi, Cidadela da Liberdade, catálogo da exposição, SESC São Paulo, 1999, e FERRAZ, Marcelo (org.). Lina Bo Bardi, Instituto Lina Bo e P. M. Bardi, São Paulo, 1993.

2. O relato completo da arquiteta sobre a concepção inicial do projeto do SESC Fábrica da Pompeia, assim como os primeiros contatos da arquiteta com os galpões da antiga fábrica de tambores, sua identificação e interesse pela estrutura de concreto, que a arquiteta teria qualificado como "belíssima", e como ela e seus colegas foram concebendo um programa para aquele espaço mais dedicado a uma ideia de recreação e à convivência através das práticas esportivas, um espaço de descanso e de lazer, ao invés de um complexo de práticas esportivas como competição, estão em um texto relato da arquiteta datado de 1986, da época da inauguração do complexo do bloco esportivo. Esse texto encontra-se reproduzido em: Instituto Lina Bo e P. M. Bardi, Cidadela da Liberdade, catálogo da exposição, SESC São Paulo, 1999, p. 27-40. Nesse mesmo texto, a arquiteta diz que o objetivo inicial do projeto de recuperação do conjunto de galpões "foi a de 'Arquitetura Pobre', isto é, não no sentido de indigência, mas no sentido artesanal que exprime Comunicação e Dignidade máximas através dos menores e humildes meios." (BO BARDI, 1986, in Instituto Lina Bo e P. M. Bardi, 1999, p. 27). Tal observação já denota a sintonia com as ideias arquitetônicas e a postura ligada à prática de uma "poética da economia"que caracterizava a produção arquitetônica de Sérgio Ferro, Rodrigo Lefèvre e Flávio Império, durante toda a década de 1960.

3. Sobre as implicações dessa transposição do escritório e outras curiosidades a respeito da construção, como a etapa em que se "descascou" todo o reboco dos galpões da antiga fábrica para se colocar em evidência a estrutura de concreto e os tijolos aparentes de vedação, veja: FERRAZ, Marcelo. Numa velha fábrica de tambores. SESC-Pompéia comemora 25 anos. Minha Cidade, São Paulo, o8.093, Vitruvius, abr. 2008, disponível no site: < http:// www.vitruvius.com.br/revistas/read/minhacidade/o8.093/1897>. Acessado em o2 de julho de 2011.

4. Sobre aspectos, características e desdobramentos do chamado "Novo Brutalismo Inglês", as críticas ao Modernismo localizadas dentro do Team $\mathrm{X}$, além das pesquisas antropológicas e a lógica estruturalista dentro da produção do arquiteto holandês Aldo Van Eyck, consultar: FRAMPTON, 
Kenneth. História Crítica da Arquitetura Moderna. São Paulo, Ed. Martins Fontes, 1997, p. 318 a 339.

5. Esse procedimento, encarado como parceria entre a "autora" do projeto e seus construtores-artesãos, também era uma prática corrente nas concepções e execuções de seus cenários teatrais, como os que realizou junto ao Teatro Oficina, para os espetáculos Gracias Señor e Na Selva das Cidades. Para maior aprofundamento nesse tema, consultar: SILVA, M. B. Lina Bo Bardi: arquitetura cênica, dissertação de mestrado, EESC-USP, São Carlos, 2004.

6. A arquitetura define-se como participativa na medida em que ela formata e condiciona o nosso corpo no espaço, nos induz a realizar determinados movimentos e a circular por ela de determinadas maneiras, seguindo a determinação dos seus corredores, portas, aberturas, caminhos, salas, etc.

Recebido em: 10/12/11

Aceito em: 15/03/12 
MARCELINA GORNI

marcelinag@gmail.com

Graduação em Arquitetura e Urbanismo pela Universidade de São Paulo - EESC-USP (1999) e mestrado pelo Programa de Pós-

Graduação em Arquitetura e Urbanismo, na mesma instituição (2004). Professora da Faculdade de Artes Visuais da Universidade Federal de Goiás - FAV-UFG. 